\title{
Melanoma of the Ciliary Body and Choroid pTO TNM Finding v7
}

National Cancer Institute

\section{Source}

National Cancer Institute. Melanoma of the Ciliary Body and Choroid pTO TNM Finding v7. NCI Thesaurus. Code C88685.

Melanoma of the ciliary body and choroid with no evidence of a primary tumor. (from AJCC 7th Ed.) 